\title{
The religious foundations of health care: a conceptual approach
}

\author{
Robert L Sevensky Department of Humanities, Pennsylvania State University
}

\section{Author's abstract}

\section{The relationship of religion and health is often} misunderstood owing to a tendency to concentrate on the medical model and to ignore the wider context of health care. A conceptual-as opposed to a historical examination of this context reveals nine central religious ideas or categories which provide an ethical foundation and heritage for medical practice and health care delivery. These include doctrines of creation; dominion or stewardship; freedom and responsibility; human dignity or sanctity of life; love or compassion; covenant; justice; vocation; and finitude. A discussion of the complementarity of religion and medicine is necessary and should proceed from these shared values and common concerns.

According to almost all the standard histories of medicine published over the last 50 years, the story of medicine is, in large part, the story of the progressive liberation of science - empirical, experimental, secular - from the religious slavery of superstition, tradition and authority. Titles such as From Witchcraft to World Health (1) or Mystery, Magic and Medicine - The Rise of Medicine from Superstition to Science (2) are indicative of such a stance. And indeed there is a truth to these claims. The development of modern medicine as we know it was too often retarded by the suspicion and even outright hostility of religious voices during centuries past.

There is another story, however, that is frequently ignored when we consider the history of religion and medicine. It is what might be called the history of the relationship of religion and health care. I say 'health care' intentionally and for two reasons. First, because from a purely historical point of view it is very difficult, if not impossible, to determine what 'medicine' might refer to in other times and in other places. Inevitably we hold up the standard of current Western medical practice as the criterion against which all other efforts to help the sick and suffering are measured and

\section{Key words}

Religion; religion and medicine; religion and science; medical ethics. defined. But such a standard includes many assumptions that may or may not apply: assumptions about the nature of reality and of human existence; about procedures, drugs and medical materials; ideas of professional education and practice, and value judgments concerning what is right or true or good. Such assumptions, however, may have little relevance to the question at hand.

More importantly, I speak of health care because even today medicine does not encompass the whole of our effort to relieve sickness and suffering, though as a society we do tend to 'medicalise' the problems of daily living and to ascribe them, in one form or another, to the domain of the physician. Many forms of health care, however, while including a major medical component, nonetheless transcend the boundaries of the traditional medical model. One thinks here, for example, of such concrete concerns as care of the poor, the aged, the physically and emotionally handicapped, and so on. And it is precisely this wider context of health care that tends to get lost in the standard histories of medicine.

An indication of this wider relationship is evident in the very language we use to talk about religion and health - language that both reflects and forms our view of reality, however subtly. This relationship is rooted in the fact that the words for health and certain central religious realities are, if not identical, at least closely related. For example, in Greek the words for saviour (soter) and for health (saos) both derive from the same root (sozo) meaning to make whole. Similarly, in Latin the terms salvus and salus both denote health and salvation; for the ancient Roman mind, the one was impossible without the other. In English the words heal, hale, holy and whole all derive from the root hal which means entire or complete . . . a family relationship capitalised upon by those who identify themselves with the so-called holistic health movement.

Such etymological developments are curious no doubt. But they are also significant, pointing as they do to a continuing history that relates religion to wider health concerns and that transcends both times and cultures.

Such a relationship can be approached in two ways. One focuses on the historical involvement of various 
religious traditions in healing practices and health care. Here, for example, we might consider the role of the healing god Asklepios in the ancient Graeco-Roman world. To his temples - which developed into rather elaborate health resorts - came the sick and suffering to seek restoration of health through a regimen of religious, cultural and physical activities.

What is surprising about such temples is the fact that those admitted were often cured, while those not cured very often went away refreshed and comforted. Why was this so? Part of the explanation lies, certainly, in the primitive forms of empirical medicine and surgery practised there. More important, however, was the intentional involvement of the person in the entirety of his or her being: as body, as mind, and as spirit. No dimension was left untreated. Neither was the sick person isolated from others; all activities were designed to integrate the person into a therapeutic community and to reconcile that person with self, with others, and with the gods or powers of nature. Such an emphasis on the whole person in community was and is characteristic of all religious healing traditions.

In a similar way we might look at the historical role of medicine or health care in the living religious traditions of the world: Judaism, Christianity, Islam, Buddhism and so on. And there is much of interest here, from the history of the founding of hospitals and hospices for the sick and dying to the codes of ethics and etiquette governing the proper therapeutic relationship between physician and patient.

Another approach is possible, however - one that focuses less on historical events and more on certain religious ideas or concepts that serve as the ethical foundation and heritage of Western health care and that even today give meaning, direction and motive to the medical enterprise. I shall describe nine salient concepts that form this basis, though others could surely be added to the list.

The first of these concepts is the notion of creation, the doctrine given its classic expression in the opening verse of the Bible: 'In the beginning God created the heavens and the earth' (3). God creates all things and pronounces them good. The world is thus not identical with God, as in some traditions. But neither is it evil and opposed to God, as in others. Neither divine nor demonic, it is simply created; as such it may be approached, investigated and even manipulated without fear. And to the extent that human beings are themselves part of the created order, they too may be studied and explored. In fact, the doctrine of creation is a central factor accounting for the rise of modern science in the Western, as opposed to the Eastern, world. Here is the traditional foundation of the scientific enterprise in all its various forms: physics, chemistry, biology, psychology and, by extension, medicine and health care. All this is made possible because the biblical doctrine frees man from regarding nature itself as sacred and inviolable.

A second related concept revolves around the issues of dominion and stewardship of this creation. And in fact, there is a tension here in Western religious tradition which is instructive. Looking once again at the book of Genesis, we see that human beings have been given 'dominion over the fish of the sea and over the birds of the air and over every living thing that moves on the earth' (4). It is for them to subdue nature. Yet that dominion has its limits, even in biblical thought. 'The earth is the Lord's,' the Psalmist tells us, and human beings are but stewards of it (5). Adam and Eve are put in the garden 'to till it and keep it'. They are not there to destroy it or mindlessly to exploit it. And in their stewardship of it, they are responsible to God.

Unfortunately the lessons of stewardship have too often been forgotten in the West on both the individual and the environmental levels. It is therefore profitable to turn to Eastern religious traditions and their strong witness to the themes of stewardship of and respect for the natural order. The concepts of harmony and moderation which characterise much of Eastern thought as well as the love of natural beauty reflected in the cultural creations and the religious philosophies of India, China and Japan can serve to balance the tendency we have in the West to stress domination, manipulation and exploitation of man and nature.

Indeed, during this century we have become increasingly aware of the fact that our ability to develop a procedure or product is, in itself, no justification for its actual development. Other justifications must be found - justifications framed by the question of our survival as a species and by the quality of that survival.

A third theme bearing on issues of sickness and health and having important implications for current medical and health concerns is that of freedom and responsibility. To be sure, no religious tradition teaches the absolute and unlimited freedom of the person in all respects and in all situations. We are all limited in some way by who we are and by the situations in which we find ourselves. Yet the great world religions also stress the reality of freedom and the need to use that freedom correctly. Whether in obeying a divine command or in seeking the truth, in performing the meritorious deed or in giving the assent of faith, human freedom is presupposed. Conversely, people must necessarily take responsibility for their decisions. There is a price to be paid for the misuse of freedom, and often that price is heavy.

The analogy in medicine and health care is apparent. None of us was born with a perfect body or, for that matter, with a perfect mind. But we are free, more or less, to decide how to use the bodies and minds with which we were born. We may, if we wish, smoke, drink excessively, engage in a stressful occupation, neglect a balanced diet or whatever. But such choices and such behaviours are not without their effects.

Two things must be said, however, in this regard. First, the price paid may be deemed worthwhile. Witness, for example, those who labour among the sick at the cost of their own health, or more dramatically, the saints and martyrs of every faith who gave their witness with their lives. Sometimes, at least, people 
rightly choose the costlier way. Second, some are not as free as others insofar as fewer or - as is sometimes the case - no options are open to them. But what then of freedom and responsibility? May we advise the person working in a hazardous occupation to leave his or her position if no alternative means of employment are available? May we urge a balanced diet on someone who cannot afford it? May we recommend the alteration of long-established behaviour when such behaviour is the very medium of significant social interaction for a particular group or subculture? In this regard, medicine and religion are alike: both must seek to increase the options for freedom, to give patients and persons the chance to choose freely among real alternatives. And for both, this may mean involvement in social, and even political, action. Only then are freedom and responsibility more than empty words. Only then do they avoid the immorality characteristic of so many popular health movements - namely, blaming the victim (6).

A fourth concept central to the development and practice of medicine and health care is that of human dignity or the sanctity of life. All life, whether human or not, merits at least some consideration on our part. We may not destroy it without giving at least some attention to its nature and purpose. Indeed, this is a central theme of Hinduism and those other Eastern traditions which see in each sentient being an immortal soul struggling to free itself from the round of birth and rebirth. If nothing else, such a view makes one think twice when considering the destruction of such a being.

For those in the Western tradition the source of human dignity springs from the doctrine which theologians call imago Dei: each of us is created in the image or likeness of God and we bear that mark for all eternity. There are, to be sure, many ways to understand this image. One might, for instance, locate it in the form or nature of the human being as such, that is to say, in some particular human capacity such as reason, creativity, or the need to live alongside other human beings. Alternatively, one might locate it in the relationship between the human being and God, whereby humans mirror in some way the divine glory. In either case, it remains true that for the care giver (physician, nurse, social worker, psychologist or whatever) the other (the patient, the client) no longer remains simply a fellow human being in distress but also a likeness of the eternal God. Such an awareness must inevitably transform the entire relationship between the two parties and make of all health care a practical recognition of the sanctity of the other.

Closely related to this insight is the teaching of love or compassion which characterises all major religions. The demand to love the neighbour which rises out of Judaism and Christianity is well known. Similar calls sound from other traditions as well. For example, in the four Illimitables or blessed dispositions of Buddhism we find loving kindness, compassion, sympathetic joy and equanimity (7). In all traditions, moreover, the love and care of the sick occupies a unique place. For instance, a significant portion of the gospel narratives is concerned with Jesus's ministry to the sick, and one of the great parables of Jesus - that of the Good Samaritan - focuses on the ministry of healing, a ministry which Christian churches have adopted over the centuries. And just as the other, the neighbour, must be seen as the image of God, so likewise in the Christian context must he or she be seen as Christ in our midst, a lesson presented in the parable of the sheep and goats in Matthew 25 with explicit reference to the care of the sick. There the glorified Christ announces: 'As you did it to one of the least of these my brethren you did it to me' (8).

Similar parables exist in other traditions. In the writings of Theravada Buddhism, for example, the Buddha is described as caring for a sick monk whose vile condition made him useless and despised of his brethren. There the Buddha teaches: 'Whoever . . . would tend me, he should tend the sick' (9). In both traditions, Christian and Buddhist, those ministering to the sick minister also to the ultimate reality that grounds all life. What a noble motive for the practice of medicine and health care!

A sixth concept worthy of attention is that of covenant. Basically, the covenant is a solemn agreement between God and his people, that in biblical times was modelled upon the formal treaties or pacts established between political entities in the ancient Near East. Such treaties served to relate the partners to each other as siblings and attempted to respect both the freedom and the obligations of each party. This was accomplished by casting the terms of the agreement in the form of overall, continuing loyalty while leaving the parties free to work out the particular details of the agreement in the give and take of daily life.

The covenant model proved remarkably enduring not only in biblical thought but in later Judaism and Christianity as well. What is particularly striking in this long history, however, is the repeated theme of God's faithfulness and love in the face of continued rejection a faithfulness and love that implies the necessity to suffer and even to die for one's covenant partner.

It comes as no surprise, then, that the covenant model has been used to elucidate the relationship between doctor and patient. In fact, William May of the Hastings Center has written at some length on the theoretical superiority of the covenant model over such alternatives as codes and contracts (10). May cites among its advantages, the place given by the covenant model to the notion of indebtedness to society and to God on the part of the doctor or health care worker; the active view of the patient as a covenant partner with certain specific obligations; the context of faithfulness and trust necessitated by the patient's vulnerability; and the ability of the covenant to avoid at least some of the rigidity and inflexibility characteristic of codes and contracts. By explicitly placing the doctor-patient relationship in a framework of shared responsibility and trust while at the same time holding fast to the legitimate demands for technical proficiency and legal 
defensibility, the covenant model effectively fosters the traditional aims of medicine and health care.

A seventh religious concept is the demand for justice sounded so strongly in the writings of the Hebrew prophets. According to this ancient and powerful tradition, God is ethical. He is not neutral vis-a-vis human action but, rather, desires that all may be treated justly and fairly. "And what does the Lord require of you but to do justice and to love kindness and to walk humbly with your God?' (11) Many see in these words of the prophet Micah the distillation of the ethical wisdom of Hebrew monotheism.

This teaching has serious and difficult consequences especially as it involves elements related to health and health care. How shall we as a nation distribute scarce medical resources? Shall we give freely to each according to what he desires or merits, or should such distribution be based on the potential of the recipient to make a contribution to society? Should we simply trust the open market place, its laws of supply and demand and the ability of the recipient to pay? Or should we give to each according to his needs, treating similar cases similarly and relying on devices such as random lotteries or upon principles such as 'first come, first served' (12)?

Difficulties mount as we extend our perspective to include not only the nation but the entire world. Is it just to spend, say, $\$ 50,000$ for one open heart operation when the same amount of money would ensure a balanced diet for hundreds of starving people for a year? Is there any justification for investing in more and better diagnostic equipment when large populations lack even the barest minimum of health care? Such questions admit of no easy answers. And here religion is of little immediate help. But the prophetic demand for justice remains important, nonetheless. It forces us to confront questions that we would all rather avoid and compels us to consider medicine and health care not only in terms of technical proficiency and accomplishment but also in terms of ethical and moral demands.

An eighth religious category is the notion of vocation or calling. Medicine, as we all know, is considered a profession, a term which itself has interesting roots in mediaeval Christianity. There it was used to describe the vows made by those entering religious life as priests, monks or nuns. Its use was later expanded to include such practical disciplines as law and medicine. And here two important elements were central, namely, the promise to be competent in one's field and the intention to place the well-being of those served above self-interest or personal gain (13).

For the religious person, however, any profession or public avowal is special, for it can always be seen as the response to a calling which has its ultimate source in some transcendent power. Such a concept of calling or vocation is ancient, playing an intimate and integral role in the biblical record beginning with the call of Abraham. And though the concept of vocation went through many changes and developments, it always remained possible to understand one's work as a particular calling from the Lord.

In a special way, medicine and health care soon became more than mere professions. Responding, perhaps, to the 'image of God' motif outlined above, supported by its increasingly successful treatment of human sickness and suffering and, perhaps most especially, influenced by the exercise of control over life and death implicit in the enterprise, medicine increasingly became understood as a response to God's call - a vocation in the literal sense of the word discovered through prayer and reflection and responded to in joy and hope. This understanding remains implicit in the self-consciousness of all religious physicians and grounds the very being of all religious health care workers.

A final concept of critical importance in the practice of health care today is that of finitude or limitation. All theistic religious traditions distinguish between God and man. Human beings are not divine. They are created a 'little less than God' (14), but fall far short of omnipotence and omniscience. They are limited and finite. And to the extent that they forget this, both as patients and as practitioners, then to that extent they set themselves up for profound disappointment.

This is a difficult lesson to learn, however. All of us want to prevent suffering and death both in ourselves and in others. That is not always possible, however, at least in this life. The religious promises of resurrection, of eternal life, of escape from suffering, or from the round of birth and death - all these are promises which find their fulfilment in another order and another age.

For the religious person, moreover, even suffering and death may have their place - not, to be sure, as things to be eagerly awaited and blithely accepted but as phenomena over which God retains ultimate control. And if one is to believe the great historic religions, God's final word will be a resounding affirmation of life and of the human effort to preserve and restore it, however fragmentary such an effort might be. In this light, we ought not to expect our attempts at helping the other always to be successful, nor may we expect all suffering or death to be abolished in this present age. To do so would be to make of medicine a new religion and of the doctor a false god. But neither are we allowed to give up this work. Supporting it are the various theological concepts outlined above as well as the fundamental religious hope that God will bring to perfection our very human, but nonetheless noble, enterprise.

\section{Conclusion}

This is but a sketch of the religious foundations of health care. The concepts described in no way form an exhaustive list. Moreover other important religious questions arise daily in the practice of medicine which are not touched upon here: Why must I suffer? What is death? How shall I die? What practical resources does religion give $m e$ in the face of inevitable suffering and death? (15). If answers to these and other questions are 
to be forthcoming, it is necessary for physicians, clergy and other interested persons to enter into dialogue and to explore together their different but complementary ministries. If we take seriously the relationship between religion and health implicit in our language, then representatives of both realms must see each other as allies in the service of the whole person. Anything less would be both bad religion and bad medicine.

\section{References}

(1) Leff S, Leff V. From witchcraft to world health. New York: Macmillan, 1956.

(2) Haggard H W. Mystery, magic and medicine - the rise of medicine from superstition to science. New York: Doubleday, 1933.

(3) Genesis 1:1. The Bible.

(4) Genesis 1:28. The Bible.

(5) Psalm 24:1. The Bible.
(6) Crawford R. You are dangerous to your health: the ideology of victim blaming. International journal of health services 1977; 7:663-680.

(7) King W L. In the hope of nibbana. La Salle, Illinois: Open Court, 1964.

(8) Matthew 25:40. The Bible.

(9) Soni $\mathbf{R} \mathrm{L}$. Buddhism in relation to the practice of medicine. In: Millard D W, ed. Religion and medicine -3. London: SCM Press, 1976: 135-151.

(10) May W. Code and covenant or philanthropy and contract? In: Reiser S J, Dyck A J, Curran W J, eds. Ethics in medicine - historical perspectives and contemporary concerns. Cambridge, Massachusetts: MIT Press, 1977: 65-76.

(11) Micah 6:8. The Bible.

(12) Outka G. Social justice and equal access to health care. Perspectives in biology and medicine 1975; 18:185-203.

(13) Pellegrino E D. Humanism and the physician. Knoxville: University of Tennessee Press, 1979.

(14) Psalm 8:5. The Bible.

(15) Sevensky R L. Religion and illness: an outline of their relationship. Southern medical journal 1981; 74:745-750.

\section{Contributors to this issue}

Ann Bowling is Senior Research Fellow, Department of Clinical Epidemiology, The London Hospital Medical College, and at the Centre for the Study of Primary Care, London.

A G M Campbell is Professor of Child Health, University of Aberdeen and Consultant Paediatrician to the Grampian Health Board.

Gillian Hanscombe is a freelance writer, journalist and teacher with an active involvement in the women's movement, and in feminist and gay journalism.

Gary E Jones is an Assistant Professor of Philosophy at the University of San Diego, California.

Clifton Perry is an Assistant Professor of Philosophy at Auburn University.

Harry Lesser is Lecturer in Philosophy at Manchester University.

François Régnier is Head of the French Unit in the Department of Clinical Research at Synthélabo LERS, Paris.
Jean-Marc Rouzioux is Professor of Legal Medicine and Toxicology at the Faculty of Medicine, University of Lyon.

Robert L Sevensky is Assistant Professor, Department of Humanities, the Milton S Hershey Medical Center, Pennsylvania State University College of Medicine.

Billie Shepperdson is Senior Research Associate at the Medical Sociology Research Centre, University College of Swansea.

Richard Sherlock is Assistant Professor in the Department of Theology at Fordham University, New York City, New York.

P J Taylor is Senior Lecturer in Forensic Psychiatry, Institute of Psychiatry, London.

American correspondent

Bernard Towers, Department of Pediatrics, University of California at Los Angeles.

Case conference editor

Roger Higgs, 81 Brixton Water Lane, London SW2 1 PH. 